\title{
Immediate Postpartum Modern Family Planning Utilization and Associated factors among women gave birth public Health facilities, Addis Ababa, Ethiopia
}

Research Article

Keywords:

Posted Date: November 19th, 2021

DOI: https://doi.org/10.21203/rs.3.rs-479663/v2

License: (1) This work is licensed under a Creative Commons Attribution 4.0 International License.

Read Full License 


\section{Abstract}

The full text of this preprint has been withdrawn by the authors due to author disagreement with the posting of the preprint. Therefore, the authors do not wish this work to be cited as a reference. Questions should be directed to the corresponding author.

\section{Full Text}

The authors have withdrawn this preprint from Research Square. 